9. Хаес С. К. Поведение основанное на правилах: Познание, случайности и контроль [Rule-governed behavior: Cognition, contingencies, and instructional control]. Нью-Йорк: Пленум Пресс. 1989.

10. Хаес С. К., Барнес-Холмс Д., Роше Б. Теория реляционных фреймов: пост-скинерианская ситуация человеческого языка и познания [Relational frame theory: A post-Skinnerian account of human language and cognition]. Нью-Йорк: Пленум Пресс. 2001.

11. Хаес С. К., Вилсон К. В., Гиффорд И. В., Фолетт В. М., Стросахл К. Эмоцилнальное избегание и поведенчиские расстройства: функциональный измерительный подход к диагностике и терапии [Emotional avoidance and behavioral disorders: A functional dimensional approach to diagnosis and treatment]. Журнал консультирование $u$ клинической психологии, 1996. № 64. С. 1152-1168.

DOI https://doi.org/10.30525/978-9934-588-80-8-1.17

\title{
ВАЖЛИВІСТЬ ПСИХОЛОГІЧНОГО ТА ФІЗИЧНОГО ЗВ'ЯЗКУ МІЖ ДИТИНОЮ ТА ОПІКУНОМ
}

\author{
Самагальська Е. Н. \\ бакалавр, \\ студент факультету прикладних наук \\ Академії ВСБ в Домброві Гурнічій \\ Домброва Гурніча, Польща
}

Багато батьків вважають, що немовля «нічого не розуміє», і те, як пройде ранне дитинство не вплине на особистість дитини та іiі подальше життя. Все більше батьків, їдучи на заробітки, залишає своїх дітей на бабусь та дідусів, що вказує на актуальність даної тематики. Ще одним важливим аспектом дослідження $є$ проблема соціалізації дітей, котрі з дитинства живуть в дитячих будинках без батьків.

Метою дослідження $є$ поглиблення знання людей в темі зв'язків між батьками та дітьми. Допомогти зрозуміти важливість дорослих у житті дітей та посприяти позитивним змінам у виховних процесах, які відбуваються у дитячих будинках.

Теорія прив'язаності разом з іiі застосуваннями в різних галузях на сьогодні $\epsilon$ найбільш широко і найбільш інтенсивно розробленою теоретичною основою. Започаткована в 1950 -х роках лікарем та психоаналітиком за освітою, Джоном Боулбі у Великобританії. Свої праці він 68 
сконцентровував на стосунках 3 опікуном, як обов'язкову умову виживання і нормального розвитку дитини. Його наступниця Мері Ейнсфорс визначила три універсальні схеми прив'язаності. Цікаво, що важливість відносин 3 опікуном для розвитку потомства була підтверджена незалежними дослідниками 3 різних країн світу та для різних видів.

Прив'язаність у теорії Боулбі - це глибокий емоційний зв'язок між дитиною та опікуном, оснований на біологічних механізмах. Формується під час першого року життя і $\epsilon$ основою майбутніх суспільних відносин.

У $60-\mathrm{x}$ роках XX століття вчений Дж. Боулбі вперше висловив думку, що потреба в особистісній прив'язаності до іншої людини $\epsilon$ вродженим інстинктом кожної людини [1, с. 54]. Твердження, що саме ця потреба є первинною, а не потреба в їжі, виявилось революційним. Боулбі стверджував, що дитина горнеться до матері не так через потребу в їжі, як заради формування прив'язаності. Це припущення було підтверджено експериментами іншого психолога - Гаррі Харлоу, який помістив мавпяче потомство в клітки з сурогатними матерями (опудало, зроблене 3 м'якої вовни, а інше - дротяний каркас 3 молоком). Дитинчата більше 17 годин на добу проводили обіймаючи вовняну сурогатну маму. I менше години провели з дротяним каркасом котрий давав їсти. В ході експерименту Харлоу створював стресові ситуації, наприклад різкий і раптовий шум. Злякавшись гучного шуму, мавпенята кидалися до опудала 3 хутром, притискалися до нього, заспокоювалися і незабаром продовжували грати.

Боулбі в своїх дослідженнях наводить результати спостереження за дітьми 3 притулків, проводячи паралель між їх поведінкою i поведінкою дитинчат мавп в ситуації стресу. Він описав цих дітей як «індивідууми із замороженими почуттями, вираженою ворожістю, антисоціальною спрямованістю і поверхневими соціальними зв'язками» $[1$, с. 88$]$.

Дослідження Мері Ейнсворт 1970 років «Незнайома Ситуація» виявило серйозний вплив прив'язаності на поведінку дитини. В ході дослідження вчені спостерігали за дітьми у віці від 12 до 18 місяців, фіксуючи їх реакцію на ситуацію, в якій вони ненадовго залишалися одні, а потім возз'єднувалися зі своїми матерями. Грунтуючись на спостереженні за реакцією дітей, Ейнсворт описала три основні стилі прив'язаності: надійний, тривожний та уникаючий. Ряд проведених пізніше досліджень показав, що кожен тип прив'язаності має сильний вплив на поведінку людини в дорослому житті. 
Сформований в дитинстві тип прив'язаності - не вічний і може змінюватися в залежності від різних факторів. Наприклад, турботлива бабуся, уважна, небайдужа няня здатні «розгорнути» дитину з уникаючою прив'язаністю, надавши їй досвід безпечної близькості. I навпаки, надійний тип прив'язаності може в міру дорослішання дитини набувати рис, наприклад, амбівалентного, через травматичну розлуку з мамою, конфлікти в сім'ї, розлучення, численні переїзди або втрати близьких родичів.

Тим не менш, це та основа, на якій потім відбувається подальший розвиток психічних процесів і особистості дитини.

Всі ми переносимо модель нашої прив'язаності на відносини 3 іншими людьми. Тобто чому навчилися в дитинстві, з тим і живемо, це й відтворюємо - 3 партнерами, друзями, дітьми.

Хейнз Кохут казав, що психічні стани, які дитина переживає разом 3 батьками заміняють їй ті психічні структури, яких на початку життя ще немає.

Експеримент психолога Едварда Троніка «Still Face Experiment» показує, що відбувається 3 дитиною коли контакт 3 опікуном переривається. Результат експерименту «still face experiment», автор описав як «щось хороше, погане та огидне». Хороше це ті нормальні відносини, увага на дитині, те що ми всі робимо для наших дітей. Погане - це коли щось сталось і дитина не може сама цього пережити, бо ще немає тих функцій і мама заспокоює ії та все знову добре. Огидне - це коли ми не даємо дитині жодної можливості повернутись до доброго і дитина застряє в цій огидній ситуації. Можемо тільки уявити, які можуть бути психічні порушення, якщо все дитинство було в такому середовищі, де дитині не давали нормальної емоційної відповіді і більшість часу ніхто не зважав на ії потреби.

Стабільні особистісні зв'язки необхідні в житті дитини. Це ії нагальна потреба з самого народження. Мозок дитини ніби кричить: «Зрозумійте мене! Любіть мене! Приділіть мені свій час, тепло, любов!». Зверніть увагу, як дитина 3 самого народження фокусується на погляді мами, потім тата, інших дорослих навколо неї. Вона ніби читає думки, намагається вгадати наші почуття, наміри, ставлення до неї.

Підсумовуючи, вищесказане, можемо зробити висновок, що перший рік життя дитини надзвичайно важливий для ії правильного психічного розвитку. Обійми, посмішки, поцілунки та добрі слова сприяють успішному формуванню правильної моделі поведінки дитини, що у майбутньому допоможе будувати дорослій людині відносити 3 друзями, колегами, партнерами та їхніми власними дітьми. 


\title{
Література:
}

1. Bowlby, J. A secure base: parent-child attachment and healthy human development. New York, Basic Books., 1988. $188 \mathrm{c}$.

2. Ainsworth M.D.S. Attachments beyond infacy. «American Psycologist». 1989.

3. Brzezińska, A.I. (red.) Psychologiczne portrety człowieka. Praktyczna psychologia rozwojowa. Gdańsk: GWP. 2005. 759 c.

4. Harwas-Napierała, B., Trempała, J. (red.) Psychoogia rozwoju człowieka. T.2, Charakterystyka okresów życia człowieka. Warszawa: PWN. 2000. 304 c.

DOI https://doi.org/10.30525/978-9934-588-80-8-1.18

\section{ВЗАЕМОЗВ'ЯЗОК ПСИХОДИНАМІЧНОЇ \\ ТА СИСТЕМНО-ДІЯЛЬНІСНОЇ ПАРАДИГМ У ПСИХОЛОГІЧНОМУ АНАЛІЗІ ПОЧЕРКУ}

\author{
Фармагей O. I. \\ доктор психологічних наук, старший науковий співробітник \\ Наџіональна академія Служби безпеки України \\ м. Київ, Украӥна
}

Почерк - це достатньо стійкий феномен, динамічний стереотип, визначений індивідуальними психофізіологічними особливостями людини. Науковці зазначають, що найбільш об'єктивним способом отримання достовірних даних про психіку людини $є$ аналіз продуктів іiі діяльності, зокрема почерку, який у більш вузькому розумінні становить продукт процесу письма. Дослідження психологічної науки останніх десятиліть свідчать про перспективність одночасного врахування кількох парадигм цієї галузі для вивчення одного й того ж феномену, який розширює практичну складову застосування доведених у такий спосіб теоретичних гіпотез, що й визначає актуальність наших пошуків.

Сучасна література підтверджує наявність широкого спектру джерел, у яких на підгрунті аналізу почерку робиться спроба діагностувати індивідуально-психологічні особливості особистості. Проте матеріалів, підтверджених відповідними науковими дослідженнями, обмаль. Переважна більшість наявних праць із проблем психодіагностики з використанням аналізу почерку не обгрунтовані науково. Вагомими дослідженнями 3 проблем психологічної діагностики 